\title{
Genotyping of Advanced Backcross Progenies Derived From Tellahamsa and MTU1010 Rice Varieties for BB and Blast Resistance Genes
}

\author{
C. Anjali ${ }^{1 *}$, Ch.V. Durga Rani ${ }^{1 *}$, M. Balram ${ }^{1}$ and Y. Chandramohan ${ }^{2}$ \\ ${ }^{1}$ Institute of Biotechnology, College of Agriculture, Professor Jayashanker Telangana State \\ Agriculture University, Rajendranagar, Hyderabad, Telangana, India \\ ${ }^{2}$ Rice Research Centre, Agricultural Research Institute, Professor Jayashanker Telangana \\ State Agriculture University, Rajendranagar, Hyderabad, Telangana, India
}

*Corresponding author

\section{Keywords \\ Rice, Bacterial blight, Blast, Marker assisted selection, $\mathrm{BC}_{3} \mathrm{~F}_{4} \& \mathrm{BC}_{4} \mathrm{~F}_{5}$ generations}

Article Info

Accepted:

26 September 2018

Available Online:

10 October 2018

\section{A B S T R A C T}

Bacterial blight (BB) and rice blast are the two most important diseases causing significant yield loss in rice, and they are endemic to several rice growing states of India. In Telangana and Andhra Pradesh states, the yield loss is very severe due to BB and blast. In order to address the above said issues, the efforts have been made by Institute of Biotechnology, Rajendranagar, Hyderabad, and developed MTU1010 and Tellahamsa introgression lines with bacterial blight ( $x a 13$ and $\mathrm{Xa21}$ ) and blast (Pi54 and Pil) resistance genes by backcrossing with donor parents. GPP2 was used as a donor for bacterial blight resistance genes ( $x a 13$ and $\mathrm{Xa21}$ ), while NLR145 (Swarnamukhi) was used as donor for blast resistance genes (Pi54 and Pil). Genotyping of these advanced backcross progenies of MTU1010 $\left(\mathrm{BC}_{4} \mathrm{~F}_{5}\right)$ and Tellahamsa $\left(\mathrm{BC}_{3} \mathrm{~F}_{4}\right)$ was carried out to check the uniformity of plants with in the progeny in homozygous condition for target genes. DNA bulking method was used to reduce the time, resources and number of samples from 3465 to 99 for DNA isolation without compromising the quality of DNA. Genotyping was carried out in 29 advanced backcross progenies $\left(\mathrm{BC}_{3} \mathrm{~F}_{4}, \mathrm{BC}_{4} \mathrm{~F}_{5}\right)$ for the presence of four target genes viz., $x a 13, \mathrm{Xa21}$, Pi54 and Pil by using gene specific / linked PCR based molecular markers viz., xa13-prom, pTA248, Pi54 MAS and RM224, respectively. The bulk sample analysis of 29 progenies exhibited uniformity for the target genes.

\section{Introduction}

Rice is a monocotyledonous angiosperm. It belongs to the genus Oryza, which contains 20 wild and two cultivated species. Oryza sativa cultivated in South Asia and Japan, while Oryza glaberrima cultivated in West Africa (Watanabe, 1976). The production of rice was 104.32 million tonnes from an area of 43.39 million hectares in India during 2015-16. Total production of rice by May 9, 2017 was 109.15 million tons in India (Ministry of Agriculture and Farmers Welfare, 2017). In India, $65 \%$ of the population depends on rice as their staple food and the country is a huge contributor to the global rice production. However, biotic and abiotic stresses are causing huge yield losses. 
MTU1010 (Cottondora Sannalu), a short duration mega rice variety released in 2000 derived from the cross Krishnaveni / IR64. This variety is extremely popular among farmers which are evident from 397.25 quintals of breeder seed indents for 2018 (http://seednet.gov.in). This variety possesses brown planthopper tolerance with long slender grains.

Tellahamsa (RNR 10754), a rice variety released from PJTSAU has become popular for rabi season because of its cold tolerance, high yielding ability and long slender grain quality. However, both the rice varieties MTU1010 and Tellahamsa are susceptible to $\mathrm{BB}$ and blast diseases, which limits their spread to areas where the two diseases are endemic.

Bacterial blight (BB), caused by Xanthomonas oryzae pv. oryzae (Xoo), is one of the serious diseases of rice across countries and can cause yield losses as high as 74 to $81 \%$ (Srinivasan and Gnanamanickam, 2005). The fungus Magnaporthegrisea is the causal agent of rice blast disease and belongs to phylum, Ascomycota and family Magnaporthaceae. It is one of the most devastating diseases in at least 85 countries worldwide. The disease often results in a significant yield loss, as high as 70 to $80 \%$ during an epidemic $(\mathrm{Ou}, 1985)$.

Nearly 40 genes conferring BB resistance have been identified (Sundaram et al., 2014) and many of them have been fine-mapped and cloned (Natrajkumar et al., 2012). 101 blastresistance genes (Rajashekara et al., 2014) and 350 quantitative trait loci (QTLs) have been identified (Sharma et al., 2012) and many are fine-mapped and a few are cloned. Closely linked or functional markers are available for many BB and blast resistance genes (Sundaram et al., 2014). As there is availability of several resistance genes to BB and blast, pyramiding multiple genes into
MTU1010 and Tellahamsa is considered as an ideal strategy to improve its resistance to these major diseases.

Gene pyramiding through conventional phenotype based breeding is considered to be difficult and often impossible, due to the dominance and epistasis effects of genes governing disease resistance and also due to limitations related to screening against the two diseases across the year (Sundaram et al., 2009). The availability of molecular markers, closely linked to or located within the resistance genes (i.e., functional markers), makes the task of gene pyramiding easier (Singh et al., 2001; Sundaram et al., 2008; Shanti et al., 2010; Zhao et al., 2014). Functional markers are developed from polymorphic sites within genes that affect target trait variation i.e. based on functional characterization of polymorphism. Hence, they are more reliable to be used in marker assisted backcross breeding, circumventing the recombination issue there by getting rid of false positives. Among the BB resistance genes identified so far, the dominant gene, $X a 21$, originally discovered from an accession of the wild rice, Oryza longistaminata confers broad spectrum resistance to many Xoo isolates in India and elsewhere. The gene has been cloned and fine-mapped on the long arm of rice chromosome 11. A PCR based STS marker, pTA248 (Ronald et al., 1992), was developed for marker assisted breeding. BB resistance gene xal3 was first discovered in the rice variety $\mathrm{BJ} 1$, mapped on the long arm of rice chromosome 8 (Ogawa et al., 1987; Zhang et al., 1996; Sanchez et al., 1999) and very tightly linked markers were identified for this gene (Sundaram et al., 2014). xa13-prom a gene specific functional PCR based marker was used for xa13 gene by several rice groups. The BB resistance gene combination, Xa21 + xal3 is known to be very effective across India (Joseph et al., 2004; Gopalakrishnan et al., 2008). 
$P i-54$, is one of the major blast resistance genes and has been observed to show resistance against many isolates of the blast pathogen in India (Ramkumar et al., 2011), which was considered as the widest spectrum resistance resource favored by the rice breeders. Pi54 gene was originally identified from Tetep, a Vietnam indica source and mapped on chromosome $11 \mathrm{~L}$ with two tightly linked simple sequence repeat (SSR) markers TRS26 and TRS33 has been cloned (Sharma et al., 2005). Ramkumar et al., 2011 developed PCR based functional marker Pi54 $M A S$ and it was observed to perfectly cosegregate with no recombinants. RM224 marker was used for Pil gene. The rice cultivar "Tetep" has been found to be resistant to most of the pathogenic races occurring in India (Padmanabhan et al., 1979). Tetep was one of the parents for NLR 145 (Swarnamukhi) variety, released from Agricultural Research Station (ARS), Nellore. The resistance of rice varieties to rice blast was mostly controlled by a pair or several pairs of main effective dominant genes.

The advanced backcross progenies of MTU1010 $\left(\mathrm{BC}_{4} \mathrm{~F}_{5}\right)$ and Tellahamsa $\left(\mathrm{BC}_{3} \mathrm{~F}_{4}\right)$ pyramided with both Bacterial blight (xal3 and $\mathrm{Xa21}$ from GPP2) and blast (Pi54 and Pil from NLR145) resistance genes were developed by Institute of Biotechnology, Rajendranagar, Hyderabad. In continuation to above research project the present research study entitled "Genotyping of advanced backcross progenies derived from Tellahamsa and MTU1010 rice varieties for BB and Blast resistance" was carried out to check the uniformity of plants with in progenies.

\section{Materials and Methods}

GPP2 and NLR145 were used as original donor parents in the recurrent backcross breeding where MTU1010 and Tellahamsa were used as recurrent parents. Subsequently advanced backcross progenies having BB and blast resistance genes were developed at Institute of Biotechnology, Rajendranagar, Hyderabad. A total of 29 advanced backcross lines of Tellahamsa $\left(\mathrm{BC}_{3} \mathrm{~F}_{4}\right)$ and MTU1010 $\left(\mathrm{BC}_{4} \mathrm{~F}_{5}\right)$ were evaluated in our study along with parental lines viz., NLR145, GPP2, MTU1010 and Tellahamsa (Table 1).

\section{Genotyping of advanced backcross progenies}

Genotyping studies were carried out to assess the homozygosity of individual plants with in each backcross progeny for all the target genes. Gene specific and closely linked gene markers were used to identify the plants carrying the target genes in homozygous condition (Table 2). This study is also known foreground selection. Genotyping was executed to identify plants possessing the target $\mathrm{R}$ genes in homozygous condition.

\section{Molecular analysis (Genotyping)}

Molecular analysis was carried out in 29 advanced backcross progenies and four parents to determine the presence of target genes in homozygous condition.

\section{Collection and preservation of leaf material}

Leaf samples were collected from advanced backcross lines of Tellahamsa (19 $\mathrm{BC}_{3} \mathrm{~F}_{4}$ lines) and MTU1010 (10 $\mathrm{BC}_{4} \mathrm{~F}_{5}$ lines) along with two recipient and two donor parents at 15 days after transplanting. Leaf samples were collected in the morning and immediately stored at $-80^{\circ} \mathrm{C}$ for DNA isolation.

\section{Bulking of leaf samples for DNA isolation}

A total of 33 (29 backcross progenies and four prarents) entries were evaluated in three replications. Thirty five plants were planted per row with a spacing of $15 \times 20 \mathrm{~cm}$. For DNA 
isolation the sample size from 3465 $(33 \times 3 \times 35=3465)$ was reduced to 99 by following DNA bulking method (Nas et al., 2002, Arunakumari, 2009 and Sravanthi, 2010). During the bulking of leaf material, precaution was taken to have uniform representation of all 35 plants present in a particular row. Leaf samples were collected from all 35 plants present in a row and bulked, thus a total of 99 bulks from a total of 3465 plants were prepared.

\section{DNA isolation}

DNA was isolated from the leaf material using a CTAB method of Zheng et al., (1996) with some modifications Quantification of isolated genomic DNA was performed by running the genomic DNA on $0.8 \%$ agarose gel (Sambrook and Russell, 2001)with diluted uncut DNA as standard.

Based on the intensity and thickness of genomic DNA bands in comparison to (lambda) DNA, the concentration and quality of DNA in individual samples was determined. Normalization of DNA samples was done to equalize the concentration of all the samples to be used for PCR reaction. The purpose of normalization was to avoid erroneous analyses due to differences in the brightness of the bands obtained after electrophoresing the PCR products.

\section{Polymerase Chain Reaction (PCR)}

PCR reaction was carried out in small PCR tubes containing $10 \mu 1 \mathrm{PCR}$ reaction mixture. The details of PCR components are furnished in the following table 3 .

Thermo cycling was carried out on a 96- well PCR system (eppendorf) which holds $0.2 \mathrm{ml}$ thin walled PCR tubes. All tubes were placed into the thermo cycler and DNA amplification program mentioned in table was followed. The annealing temperatures of the primers were standardized by using gradient PCR. The PCR program was set up with three steps per cycle and details are furnished in the following table 4.

The amplified products were resolved on $3 \%$ agarose (seakem L Agarose) gel. The gel was observed under UV trans-illuminator and gel documentation system and amplified products were visualized. The size of the amplified fragments was calculated using $50 \mathrm{bp}$ ladder (Biolabs, India) as size reference standards.

\section{Results and Discussion}

Genotyping of advanced backcross progenies were conducted to assess the uniformity of plants with in each progeny for the target genes. The DNA samples which showed amplification pattern similar to donor parent allele were considered as the uniform progeny rows, while the samples different from that of donor parent allele will be considered as segregant rows.

Molecular markers enable breeders to exercise precise selection on genotypic differences between the phenotypic expressions. The markers have the potential efficiency to increase the selection and shorten the breeding cycle (Yencho et al., 2000).

The use of molecular markers linked to resistance genes can accelerate gene pyramiding efforts and make the process more precise (Mohan et al., 1997).

In our study, 29 pooled DNA samples of advanced backcross progenies along with recurrent parents (MTU1010 and Tellahamsa) and donor parents (GPP2 for BB and NLR145 for blast resistance) were amplified for the four target genes using the following markers. The details of resistance and susceptible alleles are furnished in following table 5. 
Foreground analysis of $\mathrm{BC}_{3} \mathrm{~F}_{4}$ lines derived from Tellahamsa and $\mathrm{BC}_{4} \mathrm{~F}_{5}$ lines derived from MTU1010 for $B B$ resistance genes

Foreground analysis or foreground selection in which the breeder selects those plants having the marker allele of the donor parent at the target locus. Selection by genetic markers helps the breeder to ascertain the presence of an introgressed gene when direct phenotypic evaluation is not feasible. The objective is to maintain the target locus in a homozygous state. Foreground analysis in $\mathrm{BC}_{3} \mathrm{~F}_{4}$ lines of Tellahamsa and $\mathrm{BC}_{4} \mathrm{~F}_{5}$ lines of MTU1010 was done for two $\mathrm{BB}$ resistance genes i.e., Xa21 and $x a 13$.

Foreground selection for BB resistance genes was carried out in plants using PCR based markers, viz., pTA248 (Ronald et al., 1992) for Xa21 gene and xa13 prom (Sundaram et al., 2011) for xal3 gene which were successfully used by Magar et al., (2014), Arunakumari et al., (2016), Hajira et al., (2016) for tracking the target genes in various generations. 15 advanced backcross progenies of Tellahamsa and 10 progenies of MTU1010 carrying single or both the genes were screened using gene specific / linked markers.

Xa21 confers broad spectrum resistance (Khush et al., 1990; Ikeda et al., 1991) to many Indian isolates of Xoo. This approach of convergence breeding however can be very difficult or impossible when there is epitasis or masking effect of genes, particularly when a breeding line already harbors a gene like xal3 which shows resistance to all known Xoo races. With the conventional approach, breeding lines with $\mathrm{Xa21}$ alone cannot be distinguished from breeding lines with $\mathrm{Xa21}$ plus other BB genes. However, with the availability of DNA markers for each resistance gene, the identification of plants with multiple resistance genes would become easy (Xu et al., 1996).
Screening of advanced backcross progenies for $\mathrm{Xa21}$ gene

Fourteen progenies of Tellahamsa (TPL-53, TPL-54, TPL-55, TPL-56, TPL-57, TPL-58, TPL-59, TPL-60, TPL-65, TPL-66, TPL-68, TPL-69, TPL-70 and TPL-71) and 9 (MPL-1, MPL-3, MPL-4, MPL-5, MPL-6, MPL-7, MPL-8, MPL-9 and MPL-10) progenies of MTU1010 were evaluated in three replications. Twenty three progenies were advanced from $\mathrm{BC}_{3} \mathrm{~F}_{3}$ and $\mathrm{BC}_{4} \mathrm{~F}_{4}$ generations (Rabi, 2016-17) to the present investigation to determine the uniformity of all the plants in each progeny for $\mathrm{Xa21}$ gene. Replication wise 23 bulked DNA samples were screened using pTA248 marker along with recurrent (Tellahamsa and MTU1010) and donor (GPP2) parents. pTA248 marker used in our study is as functional marker as per the earlier report from Ronald et al., 1992. The Xa21 gene was mapped and tagged on chromosome 8 by RAPD and RFLP markers (Ronald et al., 1992) and further a PCR based STS marker pTA248 was developed which was very closely linked to the gene $(0.1 \mathrm{cM})$. According to Ronald et al., 1992, pTA248 amplified a 900 bp fragment in case of resistant genotypes while 600-800 bp fragments were observed in case of susceptible genotypes in a codominant fashion. Hence it is highly useful for marker assisted introgression of $\mathrm{Xa21}$.

Twenty three bulked DNA samples along with four parents (MTU1010, Tellahmasa, NLR145 and GPP2) were amplified and loaded on 3\% agarose gel. The gel documentation of PCR results showed 650 bp susceptible alleles in MTU1010, Tellahamsa and NLR145, while 900 bp resistance allele was observed in GPP2 (the donor parent for Xa21 gene) and all 23 advanced back cross progenies (Plate 1 pertaining to replication 1). This result clearly indicated the presence of $\mathrm{BB}$ resistance gene, $X a 21$ in all 35 plants in homozygous condition. Similar result was observed in other 
two replications too. In a marker assisted breeding study, it is desirable to verify the progenies for uniformity of target genes till the entries are promoted to advanced yield trials. DNA bulking method saved us a lot of time and resources as we could reduce the sample number from 2835 to 81 . The segregants or impurities or admixtures can be easily identified by the presence of susceptible allele or alleles in heterozygous nature. Arunakumari et al., 2009 and Sravanthi et al., 2010 used this methodology to determine the uniformity of various samples.

\section{Screening of advanced backcross progenies for $x a 13$ gene}

Thirteen progenies of Tellahamsa (TPL-53, TPL-54, TPL-55, TPL-56, TPL-57, TPL58, TPL-59, TPL-60, TPL-65, TPL-66, TPL-67, TPL-70 and TPL-71) and 7 progenies of MTU1010 (MPL-1, MPL-2, MPL-3, MPL-5, MPL-6, MPL-9 and MPL-10) were screened for xal3 gene using xal3 prom marker (Sundaram et al., 2011) along with recurrent (Tellahamsa and MTU1010) and donor parents (GPP2). Divya et al., (2015) also carried out foreground selection for the presence of $x a 13$ gene using PCR based genespecific marker, xal3 prom. xal3 prom is a functional marker designed from promoter region of xa13 gene (Sundaram et al., 2011) and it was more accurate than earlier RG136, CAPS marker which is $\sim 1.5 \mathrm{cM}$ away from xal3 gene. This marker was used for accurate genotyping by ArunaKumari and Durga Rani, 2015 as it is a perfect marker would elicit no false positive results.

Replication wise 20 bulked DNA samples were amplified with primer pair, xal3 prom and loaded on 3\% agarose gel along with four parents (MTU1010, Tellahmasa, NLR145 and GPP2). The gel documentation of PCR results showed 250 bp susceptible allele in MTU1010, Tellahamsa, NLR145, while 500 bp resistance allele was observed in all the backcross progenies. Sundaram et al., (2011), Magar et al., (2014), Padmaja et al., (2017) and many others also used this marker and observed $250 \mathrm{bp}$ and $500 \mathrm{bp}$ susceptible and resistance alleles, respectively. The results clearly revealed that $500 \mathrm{bp}$ resistance allele was observed in all 20 progenies (Plate 2 pertaining to replication 1) planted in three replications, indicating that all 35 plants present with in a progeny exhibited uniformity for $x a 13$ gene. Similar strategy was used by Arunakumari, 2009 and Sravanthi, 2010 to observe admixtures or impurities in breeder seed samples of promising rice varieties.

Table.2 Details of molecular markers used for genotyping

\begin{tabular}{|c|c|c|c|c|}
\hline S. No & Marker & Chromosome & Sequence & Reference \\
\hline 1 & $\begin{array}{l}\text { xal3 } \\
\text { prom }\end{array}$ & 8 & $\begin{array}{l}\text { F-GGCCATGGCTCAGTGTTTAT } \\
\text { R- GAGCTCCAGCTCTCCAAATG }\end{array}$ & $\begin{array}{l}\text { Sundaram et } \\
\text { al., (2011) }\end{array}$ \\
\hline 2 & pTA248 & 11 & $\begin{array}{l}\text { F-AGACGCGGGAAGGGTGGTTCCCGGA } \\
\text { R-AGACGCGGGTAATCGAAAGATGAAA }\end{array}$ & $\begin{array}{l}\text { Ronald et al., } \\
\text { (1992) }\end{array}$ \\
\hline 3 & $\begin{array}{l}\text { Pi54- } \\
\text { MAS }\end{array}$ & 11 & $\begin{array}{l}\text { F-CAATCTCCAAAGTTTTCAGG } \\
\text { R-GCTTCAATCACTGCTAGACC }\end{array}$ & $\begin{array}{l}\text { Ramkumar et } \\
\text { al., (2011) }\end{array}$ \\
\hline 4 & RM 224 & 11 & $\begin{array}{l}\text { F-ATCGATCGATCTTCACGAGG } \\
\text { R-TGCTATAAAAGGCATTCGGG }\end{array}$ & $\begin{array}{l}\text { Hittalmani et } \\
\text { al., (2000) }\end{array}$ \\
\hline
\end{tabular}


Table.1 Advanced backcross progenies of Tellahamsa and MTU1010

\begin{tabular}{|c|c|c|c|c|}
\hline S. No & $\begin{array}{l}\text { Code No. of advanced } \\
\text { backcross progenies }\end{array}$ & Generation & $\begin{array}{l}\text { Recurrent } \\
\text { parent }\end{array}$ & Target genes \\
\hline 1 & TPL-53 & $\mathrm{BC}_{3} \mathrm{~F}_{4}$ & Tellahamsa & Xa21, xa13, Pi54, Pil \\
\hline 2 & TPL-54 & $\mathrm{BC}_{3} \mathrm{~F}_{4}$ & Tellahamsa & Xa21, xa13, Pi54, Pil \\
\hline 3 & TPL-55 & $\mathrm{BC}_{3} \mathrm{~F}_{4}$ & Tellahamsa & Xa21, xa13, Pi54, Pil \\
\hline 4 & TPL-56 & $\mathrm{BC}_{3} \mathrm{~F}_{4}$ & Tellahamsa & Xa21, xa13, Pi54, Pil \\
\hline 5 & TPL-57 & $\mathrm{BC}_{3} \mathrm{~F}_{4}$ & Tellahamsa & Xa21, xa13, Pi54 \\
\hline 6 & TPL-58 & $\mathrm{BC}_{3} \mathrm{~F}_{4}$ & Tellahamsa & Xa21, xa13, Pi54 \\
\hline 7 & TPL-59 & $\mathrm{BC}_{3} \mathrm{~F}_{4}$ & Tellahamsa & Xa21, xa13, Pi54 \\
\hline 8 & TPL-60 & $\mathrm{BC}_{3} \mathrm{~F}_{4}$ & Tellahamsa & Xa21, xa13, Pi54 \\
\hline 9 & TPL-61 & $\mathrm{BC}_{3} \mathrm{~F}_{4}$ & Tellahamsa & Pi54, Pil \\
\hline 10 & TPL-62 & $\mathrm{BC}_{3} \mathrm{~F}_{4}$ & Tellahamsa & Pi54, Pil \\
\hline 11 & TPL-63 & $\mathrm{BC}_{3} \mathrm{~F}_{4}$ & Tellahamsa & Pi54, Pil \\
\hline 12 & TPL-64 & $\mathrm{BC}_{3} \mathrm{~F}_{4}$ & Tellahamsa & Pi54, Pil \\
\hline 13 & TPL-65 & $\mathrm{BC}_{3} \mathrm{~F}_{4}$ & Tellahamsa & Xa21, xa13, Pil \\
\hline 14 & TPL-66 & $\mathrm{BC}_{3} \mathrm{~F}_{4}$ & Tellahamsa & Xa21, xa13, Pil \\
\hline 15 & TPL-67 & $\mathrm{BC}_{3} \mathrm{~F}_{4}$ & Tellahamsa & xa13, Pi54, Pil \\
\hline 16 & TPL-68 & $\mathrm{BC}_{3} \mathrm{~F}_{4}$ & Tellahamsa & Xa21, Pi54, Pil \\
\hline 17 & TPL-69 & $\mathrm{BC}_{3} \mathrm{~F}_{4}$ & Tellahamsa & Xa21, Pi54, Pil \\
\hline 18 & TPL-70 & $\mathrm{BC}_{3} \mathrm{~F}_{4}$ & Tellahamsa & Xa21, xa13 \\
\hline 19 & TPL-71 & $\mathrm{BC}_{3} \mathrm{~F}_{4}$ & Tellahamsa & $X a 21, x a 13$ \\
\hline 20 & MPL-1 & $\mathrm{BC}_{4} \mathrm{~F}_{5}$ & MTU1010 & Xa21, xa13, Pi54, Pil \\
\hline 21 & MPL-2 & $\mathrm{BC}_{4} \mathrm{~F}_{5}$ & MTU1010 & xa13, Pi54, Pil \\
\hline 22 & MPL-3 & $\mathrm{BC}_{4} \mathrm{~F}_{5}$ & MTU1010 & Xa21, xa13, Pi54 \\
\hline 23 & MPL-4 & $\mathrm{BC}_{4} \mathrm{~F}_{5}$ & MTU1010 & Xa21, Pi54, Pil \\
\hline 24 & MPL-5 & $\mathrm{BC}_{4} \mathrm{~F}_{5}$ & MTU1010 & Xa21, xa13, Pil \\
\hline 25 & MPL-6 & $\mathrm{BC}_{4} \mathrm{~F}_{5}$ & MTU1010 & $X a 21, x a 13$ \\
\hline 26 & MPL-7 & $\mathrm{BC}_{4} \mathrm{~F}_{5}$ & MTU1010 & Xa21, Pi54 \\
\hline 27 & MPL-8 & $\mathrm{BC}_{4} \mathrm{~F}_{5}$ & MTU1010 & Xa21, Pil \\
\hline 28 & MPL-9 & $\mathrm{BC}_{4} \mathrm{~F}_{5}$ & MTU1010 & Xa21, xa13, Pi54, Pil \\
\hline 29 & MPL-10 & $\mathrm{BC}_{4} \mathrm{~F}_{5}$ & MTU1010 & Xa21, xa13 \\
\hline
\end{tabular}

Table.3 Components of PCR reaction

\begin{tabular}{|l|}
\hline \multicolumn{1}{|c|}{ Components } \\
\hline Template DNA \\
\hline PCR buffer \\
\hline dNTPs \\
\hline Forward Primer \\
\hline Reverse Primer \\
\hline Taq polymerase \\
\hline Sterile distilled water \\
\hline
\end{tabular}

Stock concentration $\quad$ Quantity required for one reaction $(\mu \mathrm{l})$

\begin{tabular}{|c|c|}
\hline $50 \mathrm{ng} / \mu \mathrm{l}$ & 2.0 \\
\hline $10 \mathrm{X}$ & 1.0 \\
\hline $2.5 \mathrm{Mm}$ & 1.0 \\
\hline $2.5 \mathrm{pmole}$ & 0.3 \\
\hline $2.5 \mathrm{pmole}$ & 0.3 \\
\hline $1 \mathrm{U} / \mu \mathrm{l}$ & 1.0 \\
\hline
\end{tabular}


Table.4 Thermal profile followed for PCR reaction

\begin{tabular}{|l|l|l|}
\hline Step 1 & $9^{\circ} \mathrm{C}-\mathbf{3 - 5 m i n}$ & Initial Denaturation \\
\hline Step 2 & $94^{\circ} \mathrm{C}-1 \mathrm{~min}$ & Denaturation \\
\hline Step 3 & $50-65^{\circ} \mathrm{C}-30 \mathrm{sec}$ & Annealing- based on melting temp of primer \\
\hline Step 4 & $70-72^{\circ} \mathrm{C}-$ variable & Extension- based on size of amplicons \\
\hline Step 5 & Repeat step 2-4 for 30-45 times \\
\hline Step 6 & $72^{\circ} \mathrm{C}-7 \mathrm{~min}$ & Final Extension \\
\hline Step 7 & Hold at $4^{\circ} \mathrm{C}$ till loading on Agarose gel electrophoresis \\
\hline
\end{tabular}

Table.5 Resistance and susceptible allele sizes of target gene specific / linked markers

\begin{tabular}{|l|c|c|c|c|}
\hline Gene & Markers & Resistance allele & Susceptible allele & Reference \\
\hline xa13 & xa13-prom & $500 \mathrm{bp}$ & $250 \mathrm{bp}$ & Sundaram et al., 2011 \\
\hline Xa21 & PTA248 & $900 \mathrm{bp}$ & $650 \mathrm{bp}$ & Ronald et al., 1992 \\
\hline Pi54 & Pi54 MAS & $200 \mathrm{bp}$ & $350 \mathrm{bp}$ & Ramkumar et al., 2011 \\
\hline Pi1 & RM224 & $130 \mathrm{bp}$ & $150 \mathrm{bp}$ & Hittalmani et al., 2000 \\
\hline
\end{tabular}

Plate.1 Genotyping of advanced backcross progenies for Xa21 gene using pTA248 marker

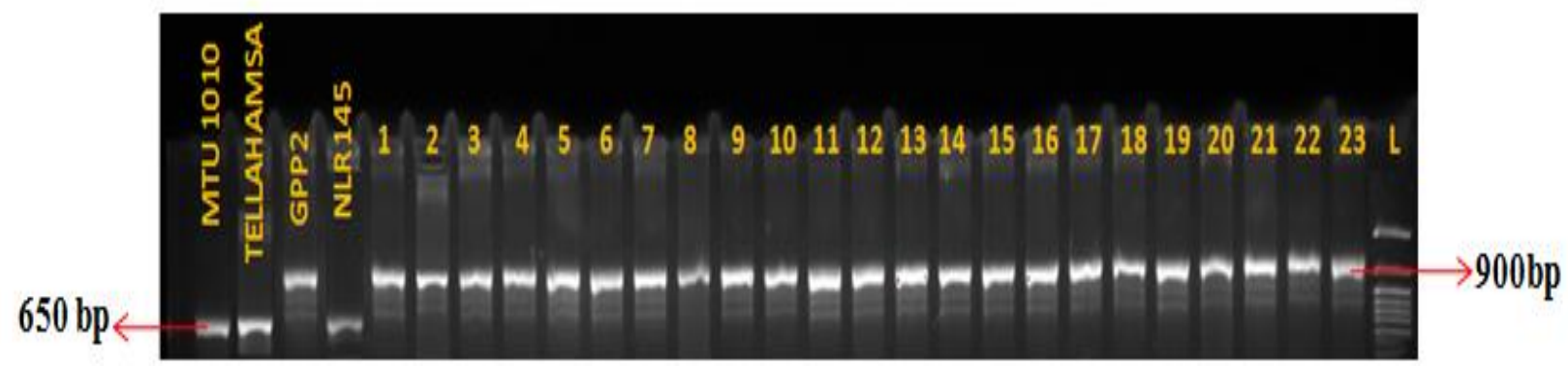

L- 50 bp DNA ladder, resistance allele size- 900 bp, susceptible allele size- 650 bp

MTU 1010 and Tellahamsa- Recipient parents

GPP2- donor parent for BB resistance genes ( $x a 13$ and Xa21)

NLR 145- donor parent for blast resistance genes (Pi54 and Pil)

1-23 indicate bulked DNA samples of advanced back cross progenies

\begin{tabular}{|l|l|l|l|l|l|l|l|}
\hline S.No & Entries & S.No & Entries & S.No & Entries & S.No & Entries \\
\hline $\mathbf{1}$ & TPL-53 & 7 & TPL-59 & 13 & TPL-70 & 19 & MPL-6 \\
\hline $\mathbf{2}$ & TPL-54 & 8 & TPL-60 & 14 & TPL-71 & 20 & MPL-7 \\
\hline $\mathbf{3}$ & TPL-55 & 9 & TPL-65 & 15 & MPL-1 & 21 & MPL-8 \\
\hline $\mathbf{4}$ & TPL-56 & 10 & TPL-66 & 16 & MPL-3 & 22 & MPL-9 \\
\hline $\mathbf{5}$ & TPL-57 & 11 & TPL-68 & 17 & MPL-4 & 23 & MPL-10 \\
\hline $\mathbf{6}$ & TPL-58 & 12 & TPL-69 & 18 & MPL-5 & & \\
\hline
\end{tabular}


Plate.2 Genotyping of advanced backcross progenies for xal3 gene using xal3 prom marker

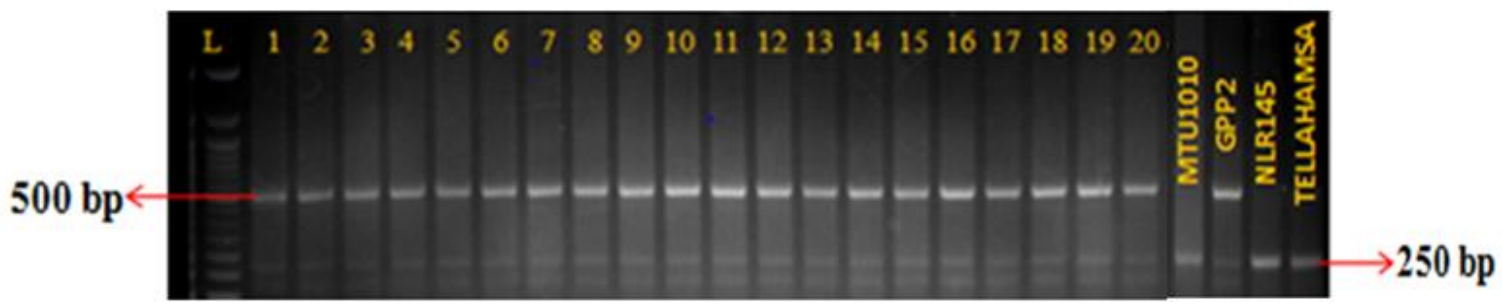

L- 50 bp DNA ladder, resistance allele size- 500 bp, susceptible allele size- 250 bp

MTU 1010 and Tellahamsa- Recipient parents

GPP2- donor parent for BB resistance genes ( $x a 13$ and $\mathrm{Xa21}$ )

NLR 145- donor parent for blast resistance genes (Pi54 and Pil)

1-20 indicate bulked DNA samples of advanced back cross progenies

\begin{tabular}{|l|l|l|l|l|l|}
\hline S.No & Entries & S.No & Entries & S.No & Entries \\
\hline $\mathbf{1}$ & TPL-53 & 8 & TPL-60 & 15 & MPL-2 \\
\hline $\mathbf{2}$ & TPL-54 & 9 & TPL-65 & 16 & MPL-3 \\
\hline $\mathbf{3}$ & TPL-55 & 10 & TPL-66 & 17 & MPL-5 \\
\hline $\mathbf{4}$ & TPL-56 & 11 & TPL-67 & 18 & MPL-6 \\
\hline $\mathbf{5}$ & TPL-57 & 12 & TPL-70 & 19 & MPL-9 \\
\hline $\mathbf{6}$ & TPL-58 & 13 & TPL-71 & 20 & MPL-10 \\
\hline 7 & TPL-59 & 14 & MPL-1 & & \\
\hline
\end{tabular}

Plate.3 Genotyping of advanced backcross progenies for Pi54 gene using Pi54 MAS marker

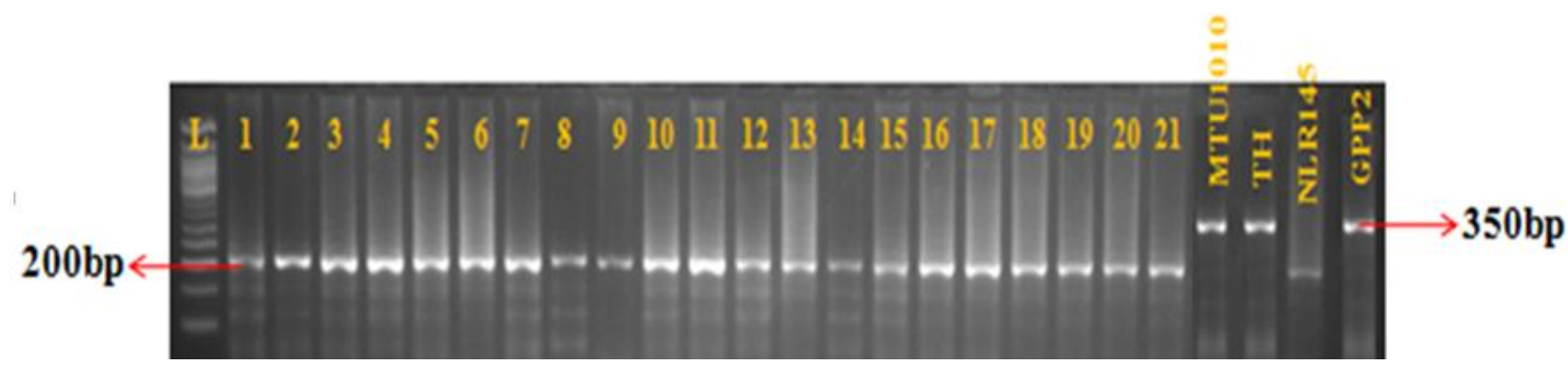

L- 50bp ladder, resistance allele size- $200 \mathrm{bp}$, susceptible allele size- $350 \mathrm{bp}$

MTU 1010 and Tellahamsa- Recipient parents, GPP2- donor parent for BB resistance genes ( $x a 13$ and Xa21)

NLR 145- donor parent for blast resistance genes (Pi54 and Pil)

1-21 indicate bulked DNA samples of advanced back cross progenies

\begin{tabular}{|l|l|l|l|l|l|}
\hline S. No & Entries & S.No & Entries & S.No & Entries \\
\hline $\mathbf{1}$ & TPL-53 & 8 & TPL-60 & 15 & TPL-69 \\
\hline $\mathbf{2}$ & TPL-54 & 9 & TPL-61 & 16 & MPL-1 \\
\hline $\mathbf{3}$ & TPL-55 & 10 & TPL-62 & 17 & MPL-2 \\
\hline $\mathbf{4}$ & TPL-56 & 11 & TPL-63 & 18 & MPL-3 \\
\hline $\mathbf{5}$ & TPL-57 & 12 & TPL-64 & 19 & MPL-4 \\
\hline $\mathbf{6}$ & TPL-58 & 13 & TPL-67 & 20 & MPL-7 \\
\hline $\mathbf{7}$ & TPL-59 & 14 & TPL-68 & 21 & MPL-9 \\
\hline
\end{tabular}


Plate.4 Genotyping of advanced backcross progenies for Pil gene using RM224 marker

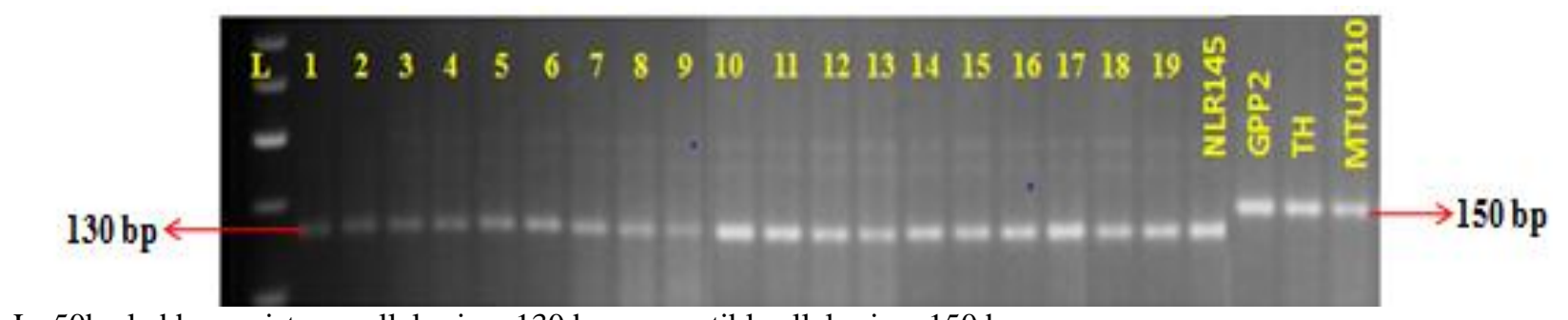

L- $50 \mathrm{bp}$ ladder, resistance allele size- $130 \mathrm{bp}$, susceptible allele size- $150 \mathrm{bp}$

MTU 1010 and Tellahamsa- Recipient parents, GPP2- donor parent for BB resistance genes (xa13 and Xa21)

NLR 145- donor parent for blast resistance genes (Pi54 and Pil)

1-19 indicate bulked DNA samples of advanced back cross progenies

\begin{tabular}{|l|l|l|l|l|l|}
\hline S.No & Entries & S.No & Entries & S.No & Entries \\
\hline $\mathbf{1}$ & TPL-53 & 8 & TPL-64 & 15 & MPL-2 \\
\hline $\mathbf{2}$ & TPL-54 & 9 & TPL-65 & 16 & MPL-4 \\
\hline $\mathbf{3}$ & TPL-55 & 10 & TPL-66 & 17 & MPL-5 \\
\hline $\mathbf{4}$ & TPL-56 & 11 & TPL-67 & 18 & MPL-8 \\
\hline $\mathbf{5}$ & TPL-61 & 12 & TPL-68 & 19 & MPL-9 \\
\hline $\mathbf{6}$ & TPL-62 & 13 & TPL-69 & & \\
\hline $\mathbf{7}$ & TPL-63 & 14 & MPL-1 & & \\
\hline
\end{tabular}

Foreground analysis of $\mathrm{BC}_{3} \mathrm{~F}_{4}$ lines derived from Tellahamsa and $\mathrm{BC}_{4} \mathrm{~F}_{5}$ lines derived from MTU1010 for blast resistance genes

Foreground analysis was done in $\mathrm{BC}_{3} \mathrm{~F}_{4}$ lines derived from Tellahamsa and $\mathrm{BC}_{4} \mathrm{~F}_{5}$ lines derived from MTU1010 for observing uniformity of blast resistance genes i.e., Pi54 and Pil. In the current study, foreground selection for blast resistance genes was carried out using PCR based markers, viz., Pi54 MAS (Ramkumar et al., 2011) for Pi54 gene and RM224 (Hittalmani et al., 2000) for Pil gene. Seventeen advanced backcross progenies of Tellahamsa and 8 progenies of MTU1010 carrying single or both the genes were screened.

\section{Screening of advanced backcross progenies} for Pi54 gene

A total of 15 progenies of Tellahamsa (TPL53, TPL-54, TPL-55, TPL-56, TPL-57, TPL58, TPL-59, TPL-60, TPL-61, TPL-62, TPL-
63, TPL-64, TPL-67, TPL-68 and TPL69) and 6 progenies of MTU1010 (MPL-1, MPL-2, MPL-3, MPL-4, MPL-7 and MPL-9) in three replications were screened using Pi54MAS marker along with recurrent (Tellahamsa and MTU1010) and donor (NLR145) parents

The resistance allele size was noted as $200 \mathrm{bp}$ whereas susceptible allele is of $350 \mathrm{bp}$. The gene $P i-k h$ from Tetep (an indica rice line) is highly effective against the pathogen population found in the Northwestern Himalayan region of India (Sharma et al., 2002). Linkage analysis of the 208 individual plants in the mapping population with four rice markers and a CAPS marker revealed that (Sharma et al., 2005a) S129700 and RM 206 were linked to the $P i-k h$ locus at distances of $4.5 \mathrm{cM}$ distance and $0.7 \mathrm{cM}$ distance $\mathrm{cM}$, respectively (Sharma et al., 2005b). Subsequently a PCR-based co-dominant molecular marker Pi-54 MAS was developed (Ramkumar et al., 2011) which could effectively amplify Pi54 gene compared to 
the earlier reported markers. Twenty one bulked DNA samples along with four parents (MTU1010, Tellahmasa, GPP2 and NLR145) were amplified with primer pair, Pi54 MAS and loaded on 3\% agarose gel. The gel documentation of PCR results exhibited 350bp susceptible allele in MTU1010, Tellahamsa and GPP2) and 200bp resistance allele was observed in NLR145, the donor parent for Pi54 gene. The results further revealed that $200 \mathrm{bp}$ resistance allele was observed in all 21 progenies (Plate 3 showing the progenies obtained from replication one) indicating that all 35 plants present in each progeny expressed resistance allele like NLR145 without any segregation. In a selfpollinated crop like rice as per the expectation, the gene will be fixed once we select the homozygous plant with $\mathrm{Pi} 54$ gene from $\mathrm{F}_{2}$ population. Madhavi et al., (2012), Atulsingh et al., (2012) and Hari et al., (2013) also used Pi54 MAS for confirmation of Pi54 gene in segregating populations and further generations.

\section{Screening of advanced backcross progenies for Pil gene}

A total of 13 progenies of Tellahamsa (TPL53, TPL-54, TPL-55, TPL-56, TPL-61, TPL62, TPL-63, TPL-64, TPL-65, TPL-66, TPL67, TPL-68 and TPL-69) and 6 progenies of MTU1010 (MPL-1, MPL-2, MPL-4, MPL-5, MPL-8 and MPL-9) in three replications were screened for Pil gene using RM224 marker along with parents. According to Collard and Mackill (2008), the markers to be used should be close to gene of interest $(<5$ recombination unit or $\mathrm{cM}$ ) in order to ensure that only minor fraction of the selected individuals will be recombinants. The SSR marker RM224 was chosen in our study because it is mapped in the same position $(0.0 \mathrm{cM})$ as with the Pil gene. It is recognized as valuable marker for introgression and pyramiding of $\mathrm{Pil}$ gene into blast susceptible rice cultivars (Fuentes et al.,
2008). This was successfully used in several marker assisted breeding programmes for efficient selection. Hence RM224 marker for Pil gene screening was used in our study

Nineteen bulked DNA samples were amplified by using RM224 for Pil and loaded on $3 \%$ agarose gel along with four parents (MTU1010, Tellahmasa, GPP2 and NLR145). The gel documentation of PCR products shown 150 bp susceptible alleles in MTU1010, Tellahamsa and GPP2 and $130 \mathrm{bp}$ resistance allele in all the 19 progenies and the donor parent, NLR145. This result indicated the presence of resistance gene in homozygous condition in them. The Plate 4 is showed the uniformity of 19 progenies in first replication for Pil gene. Similar results were observed in the works of Liu et al., (2003), Prasad et al., (2009), Jiang et al., (2012) and Balakrishanan et al., (2013).

DNA bulking method was used to reduce the time and number of samples for DNA isolation without compromising the quality of the test. Equal quantity of leaf sample was collected from all 35 single plants present in a row towards bulk DNA isolation.

Genotyping of 29 advanced backcross progenies for the presence of four target genes (xa13, Xa21, Pi54 and Pil) by using gene specific / gene linked PCR based molecular markers viz., xa13-prom, pTA248, Pi54 MAS and RM224, respectively was carried out.

The bulk sample analysis of 29 progenies exhibited uniformity of all the plants for the target genes.

\section{Acknowledgements}

The authors are thankful to Department of Biotechnology (BT/PR/11705/AGR/02/646/ 2008), Government of India, New Delhi, for providing financial support and PJTSAU, 
Rajendranagar, Hyderabad for field and laboratory facilities to carry out the research.

\section{References}

Aruna Kumari, K and Durga Rani, Ch. V. 2015. Validation of gene targeted markers linked to the resistance genes viz., xa13, $\mathrm{Xa21}$ and Pi54 in Parents. International Journal of Scientific Research. 4 (1): 420422.

Aruna Kumari, K. 2009. Assessment of genetic purity in rice cultivar, SambaMahsuri (BPT 5204) using SSR markers. M.Sc Thesis. Acharya N.G. Ranga Agricultural University, Hyderabad, India.

Arunakumari, K., Durgarani, C.V., Satturu, V., Sarikonda, K.R., Chittoor, P.D.R., Vutukuri, B., Laha, G.S., Nelli, A.P.K., Gattu, S., Jamal, M., Prasadbabu, A., Hajira, S and Sundaram, R.M. 2016. Marker-Assisted Pyramiding of Genes Conferring Resistance against Bacterial Blight and Blast Diseases into Indian Rice Variety MTU1010. Rice Science. 23(6): 306-316.

Atul Singh., Singh, K.V., Singh, S.P., Pandian, R.T.P., Ranjith, E.K., Devinder Singh., Bhowmick, K.P., Gopala Krishnan, S., Nagarajan, M., Vinod, K.K., Singh, U.D., Prabhu, K. V., Sharma, T.R., Mohapatra, $\mathrm{T}$ and Singh, A.K. 2012. Molecular breeding for the development of multiple disease resistance in Basmati rice., www.aobplants.oxfordjournals.org.

Balakrishnan, D., Robin, S., Rabindran, R., Senthil, S., Ravendran, M and John Joel, A. 2013. Marker assisted backcross breeding approach to improve blast resistance in Indian rice (Oryza sativa) variety ADT43. Euphytica. 200: 61-77.

Collard, B.C.Y and Mackill, M.J. 2008. Marker assisted selection: an approach for precision plant breeding in the twenty first century. Philosophical Transactions of the Royal Society B. 363: 557-572.

Divya, D., Bhaskar, N.S., Sundaram, R.M., Laha, G.S and Bentur, J.S. 2015. Marker- assisted pyramiding of bacterial blight and gall midge resistance genes in Samba Mahsuri and study of their interactions. International Journal of Scientific Research. 4(6): 591-594.

Fuentes, J.L., Correa Victoria, F.J., Escobar, F., Prado, G., Aricapa, G., Duque, M.C and Thome, J. 2008. Identification of microsatellite markers linked to the blast resistance gene $P i-1(t)$ in rice. Euphytica. 160: 295-304.

Gopalakrishnan, S., Sharma, R.K., AnandRajkumar, K., Joseph, M., Singh, V.P., Singh, A.K., Bhat, K.V., Singh, N.K and Mohapatra, T. 2008. Integrating marker assisted background analysis with foreground selection for identification of superior bacterial blight resistant recombinants in Basmati rice. Plant Breeding. 127: 131-139.

Hajira, S.K., Sundaram, R.M., Laha, G.S., Yugander, A., Balachandran, S.M., Viraktamath, K., Sujatha, B.C., Balachiranjeevi, C.H., Pranathi, K., Anila, M., Bhaskar, S., Abhilash, V., Mahadevaswamy, H.K., Kousik, M., Dilip Kumar, T., Harika, G and Rekha G. 2016. A Single-Tube, Functional MarkerBased Multiplex PCR Assay for Simultaneous Detection of Major Bacterial Blight Resistance Genes Xa21, xal3 and $x a 5$ in Rice. Rice Science. 23(3): 144-151.

Hari, Y., SrinivasaRao, K., Viraktamath, B.C., Hariprasad, A.S., Laha, G.S., Ahmed, M., Natarajkumar, P., Sujatha, K.K., Srinivasprasad, M.S., Rani, N.S., Balachandra, S.M., Kemparaju., Mohan, K.M., Sama, V.S.A.K., Shaik, H., Balachiranjeevi, Ch., Pranathi, K., Reddy, G.A., Madhav, M.S and Sundaram, R.M. 2013. Marker-assisted introgression of bacterial blight and blast resistance into IR 58025b, an elite maintainer line of rice. Journal of Plant Breeding. 132: 586594.

Hittalmani, S., Parco, A., Mew, T.V., Zeigler, R.S and Huang, N. 2000. Fine mapping and DNA marker assisted pyramiding of 
the three major genes for blast resistance in rice. Theoretical and Applied Genetics. 100: 1121-1128.

http://seednet.gov.in

Ikeda, R., Tabien, R.E and Khush, G.S. 1991. Chromosomal location of Xa-21. Rice Genetics.RGN9:128-129.

Jiang, H. C., Feng, Y. T., Bao L, Li, X., Gao, G. J., Zhang, Q. L., Xiao, J. H., Xu, C. G and He, Y. Q. 2012. Improving blast resistance of Jin 23B and its hybrid rice by marker-assisted gene pyramiding.

Joseph, M., Gopalakrishnan, S., Sharma, R.K., Singhm, V.P., Singhm, A.K., Singhm, N.K and Mohapatra, T. 2004. Combining bacterial blight resistance and Basmati quality characteristics by phenotypic and molecular marker assisted selection in rice. Molecular Breeding., 13: 377- 387.

Khush, G.S., Bacalango, E. and Ogawa, T. (1990). A new gene for resistance to bacterial blight from Oryza longistaminata. Rice Genetics Newsletter. 12: $9-115$.

Liu, S.P., Li, X., Wang, C.Y., Li, X.H and He, Y.Q. 2003. Improvement of resistance to rice blast in Zhenshan 97 by molecular marker-aided selection. ActaBotanicaSinica. 45: 1346-1350.

Madhavi, K., Ratna Prasad, M., SrinivasMadhav, M., Sheshu, Laha, G.S., Mohan, K. M., Sundaram, R.M., Jahnavi, B., Vijitha, S., Rao, P.R and Viraktamath, B.C. 2012.Introgression of Blast Resistance Gene $P i$-kh into Elite indica Rice Variety Improved Samba Mahsuri. Indian Journal of Plant Protection. 40(1): 52- 56.

Magar, M.M., Durga Rani, Ch.V., Vanisree, S., Jamaloddin, M.d., Swathi, G., Sheshumadhav, M., Anuradha, G., Sri Chandana, B and Siddiq, E.A. 2014. Marker assisted selection for identification of recombinants for bacterial blight and blast resistance in segregating populations of Cottondora Sannalu. Oryza. 51:105-115.

Ministry of agriculture and farmers welfare. 2017.
Mohan, M., Nair, S., Bhagwat, A., Krishna, T.G., Yano, M., Bhatia, C.R and Sasaki, T. 1997. Genome mapping, molecular markers and marker-assisted selection in crop plants. Molecular Breeding. 3: 87103.

Nas, T.M., Toledo, R.S., Li, Z and Virmani, S.S. 2002. Two-dimensional DNA sampling: a new strategy for assessing hybridity using molecular markers. Publication of Proceedings of 4 th International Symposium on Hybrid Rice, Hanoi. Pp. 14-17.

Natrajkumar, P., Sujatha, K., Laha, G.S., Srinivasarao, K., Mishra, B., Viraktamath, B.C., Hari, Y., Reddy, C.S., Balachandran, S.M., Ram, T., Sheshumadhav, M., Shobharani, N., Neeraja, C.N., Ashokreddy, G., Shaik, H and Sundaram, R.M. 2012. Identification and fine-mapping of Xa33, a novel gene for resistance to Xanthomonas oryzae $p v$. oryzae. Phytopathology. 102: 222-228.

Ogawa, T., Lin, L., Tabien, R.E and Khush, G.S. 1987. A new recessive gene for resistance to bacterial blight of rice. Rice Genetics News Letter. 14: 98-100.

Ou, S.H. 1985. Rice diseases, 2nd edition, Common Wealth Mycological Institute, Kew, UK.

Padmaja, G., Durga rani, CH.V., Uma devi, G., Yugander, A., Srinivas, C and Sundaram, R.M. 2017. Multi-location evaluation of gene pyramided lines of MTU1010 and JGL 1798 against bacterial blight of rice. Indian Phytopathology. 70(3): 287-293.

Padmanabhan, S.Y. 1979. Blast resistance in India. Rice Blast Workshop. International Rice Research Institute, Philippinnes. 4361.

Prasad, M.S., Kanthi, B.A., Balachandran, S.M., Seshumadhav, M., Mohan, K.M and Viraktamath, B. C. 2009. Molecular mapping of rice blast resistance gene $P i$ $1(\mathrm{t})$ in the elite indica variety Samba mahsuri. World Journal Microbiology Biotechnology.25: 1765-1769.

Rajashekara, H., Ellur, R.K., Khanna, A., Nagarajan, M., Gopala Krishnan, S., 
Singh, A. K., Sharma, P., Sharma, T.R and Singh U D. 2014. Inheritance of blast resistance and its allelic relationship with five major $\mathrm{R}$ genes in a rice landrace 'Vanasurya'. Indian Phytopathological Society. 67(4): 365-369.

Ramkumar, G., SrinivasaRao, K., Madhan Mohan, K., Sudarshan, I., Sivaranjani, A.K.P., Gopala Krishna, K., Neeraja, C.N., Balachandran, S.M., Sundaram, R.M., Prasad, M.S., Shobha Rani, N., Ram Prasad, A.M., Virakmath, B.C and Madhav, M.S. 2011. Development and validation of functional marker targeting an In Del in the major rice blast disease resistance gene Pi54 (Pikh). Molecular Breeding. 27: 129-135.

Ronald, P.C., Albano, B., Tabien, R., Abenes, L., Wu, K., McCouch, S.R and Tanksley, S.D. 1992. Genetic and physical analysis of the rice bacterial blight disease resistance locus, Xa21. Molecular Genetics and Genomics. 236: 113-120.

Sambrook, J and Russell, D. W. 2001. Molecular cloning: A laboratory manual. Cold Spring Harbour Laboratory Press, Cold Spring Harbour, New York.

Sanchez, A.C., Ilag, L.L., Yang, D., Brar, D.S., Ausubel, F., Khush, G.S., Yano, M., Sasaki, T., Li, Z and Huang, N. 1999. Genetic and physical mapping of $x a 13$, a recessive gene bacterial blight resistance gene in rice. Theoretical and Applied Genetics. 98: 1022-1028.

Shanti, L. M., Lalithadevi, G., Naveen kumar, G and Shashidhar, H.E. 2010. Molecular marker assisted selection. A tool for insulating parental lines of hybrid rice against Bacterial Leaf Blight. International Journal of Plant Pathology. 1(3):114-123.

Sharma, T.R., Chauhan, R.S., Singh, B.M., Paul, R., Sagar, V and Rathore, R. 2002. RAPD and pathotype analysis of Magnaporthegrisea population from North-western Himalayan region of India. Journal of Phytopathology. 150: 649-656.

Sharma, T.R., Madhav, M.S., Singh, B.K., Shanker, P., Jana, T.K., Dalal, T., Pandit,
A., Singh, A., Gaikwad, K., Upreti, H.C and Singh, N.K. 2005a. High resolution mapping, cloning and molecular characterization of the Pikh gene of rice, which confers resistance to $M$. grisea. Molecular Genetics and Genomics. 274: 569-578.

Sharma, T.R., Rai, A.K., Gupta, S.K., Vijayan, J., Devanna, B.N and Ray, S. 2012. Rice Blast Management Through Host-Plant Resistance: retrospect and Prospects. Agricultural research: 37-52.

Sharma, T.R., Shanker, P., Singh, B.K., Jana, T.K., Madhav, M.S., Gaikwad, G., Singh, N.K., Plaha, P and Rathour, R. 2005b. Molecular mapping of rice blast resistance gene $P i-k h$ in rice variety Tetep. Journal of Plant Biochemistry and Biotechnology. 14: 127-133.

Singh, S., Sidhu, J.S., Huang, N., Vikal, Y., Li, Z., Brar, D.S., Dhaliwal, H.S and Khush, G.S. (2001). Pyramiding three bacterial blight resistance genes ( $x a 5, x a 13$ and $\mathrm{Xa21)}$ using marker- assisted selection into indica rice cultivar PR-106. Theoritical Applied Genetics. 102:10111015.

Sravanthi, P. 2010. Molecular identity for the elite rice variety Samba Mahsuri (BPT 5204) using SSR markers. M.Sc. Thesis. Acharya N.G. Ranga Agricultural University, Hyderabad, India.

Srinivasan, B and Gnanamanickam, S. 2005. Identification of a new source of resistance in wild rice, Oryza rufipogon to bacterial blight of rice caused by Indian strains of Xanthomonas oryzae $p v$. oryzae. Current Science. 88:25.

Sundaram, R.M., Laha, G.S., Viraktamath, B.C., Sujatha, K., Natarajkumar, P., Hari, Y., SrinivasaRao, K., Reddy, C.S., Balachandran, S.M., Madhav, M.S., Hajira, S.K., Rani, N.S., Vishnupriya, M.R and Sonti, R.V. 2011. Marker assisted breeding for development of Bacterial blight resistant rice. Genomics and Crop Improvement: Relevance and Reservations. 154-182.

Sundaram, R.M., Priya, M.R.V., Biradar, S.K., 
Laha, G.S., Reddy, G.A., Rani, N.S., Sharma, N.P. and Sonti, R.V. 2008. Marker assisted introgression of bacterial blight resistance in Samba Mahsuri, an elite indica rice variety. Euphytica. 160: $411-422$.

Sundaram, R.M., Priya, M.R.V., Laha, G.S., Shobha Rani, N., SrinivasaRao, P., Balachandran, S.M., Ashok Reddy, G., Sarma, N.P and Sonti, R.V. 2009. Introduction of bacterial blight resistance into Triguna, a high yielding, mid-early duration rice variety by molecular marker assisted breeding. Biotechnology Journal. 4: 400-407.

Sundaram, R.M., Subhadeep, C., Ricardo, O., Laha, G.S., Jan, E., Ramesh., Sonti, V and Casiana, V.C. 2014. Update on Bacterial Blight of Rice: Fourth International Conference on Bacterial Blight. Rice. 7:12. 32.

Watanabe, S. (1976). Studies on the breeding of rice varieties resistant to bacterial leaf blight in Sri Lanka. Bull. Tohoku Natl. Agriculture Experiment Station. 54: 1 74.
Xu, J.L., Lin, Y.Z., Weng, J.P and Zhao, X.L. 1996. Convergence of genes for resistance to bacterial blight in rice and its genetics. ActaAgron Sin. 22: 129-134.

Yencho, G.C., Cohen, M.B and Byrne, P.F. 2000. Applications of tagging and mapping insect resistance loci in plants. Annual Review of Entomology. 45: 393422.

Zhang, G., Angeles, E.R., Abenes, M.L.P., Khush, G.S and Huang, N. 1996. RAPD and RFLP mapping of the bacterial blight resistance gene $x a 13$ in rice. Theoretical and Applied Genetics. 93: 65-70.

Zhao, G. Z., Jiang, C.M., Liu, J. X., Chen, Y.M., Yu, T.Q and Cheng, Z.Q. 2014. Identification and analysis on the rice blast resistance gene $P i$-ta in wild rice from Yunnan, China. Chinese Journal of Rice Science. 28(6): 675-680.

Zheng, K., Subudhi, P.K., Domingo, J., Maopanty, G and Huang, N. 1996. Rapid DNA isolation for marker assisted selection in rice breeding. Rice Genetics News Letter. 12: 255-258.

\section{How to cite this article:}

Anjali, C., Ch.V. Durga Rani, M. Balram and Chandramohan, Y. 2018. Genotyping of Advanced Backcross Progenies Derived From Tellahamsa and MTU1010 Rice Varieties for BB and Blast Resistance Genes. Int.J.Curr.Microbiol.App.Sci. 7(09): 3726-3740. doi: https://doi.org/10.20546/ijcmas.2018.709.462 